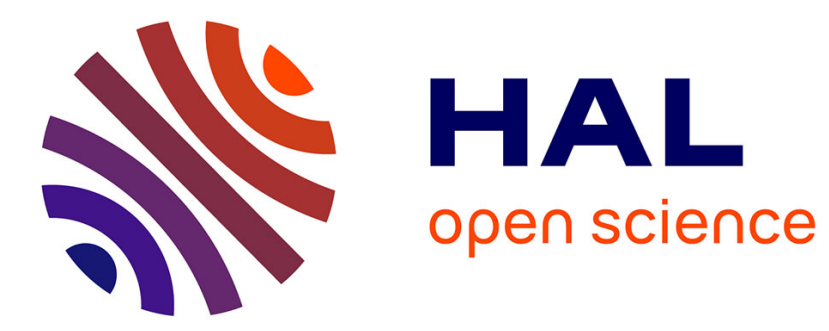

\title{
Organic matter characterisation and turnover in the sediment and seawater of a tourist harbour
}

Cristina Misic, Anabella Covazzi Harriague

\section{To cite this version:}

Cristina Misic, Anabella Covazzi Harriague. Organic matter characterisation and turnover in the sediment and seawater of a tourist harbour. Marine Environmental Research, 2009, 68 (5), pp.227. 10.1016/j.marenvres.2009.06.012 . hal-00520356

\section{HAL Id: hal-00520356 https://hal.science/hal-00520356}

Submitted on 23 Sep 2010

HAL is a multi-disciplinary open access archive for the deposit and dissemination of scientific research documents, whether they are published or not. The documents may come from teaching and research institutions in France or abroad, or from public or private research centers.
L'archive ouverte pluridisciplinaire HAL, est destinée au dépôt et à la diffusion de documents scientifiques de niveau recherche, publiés ou non, émanant des établissements d'enseignement et de recherche français ou étrangers, des laboratoires publics ou privés. 


\section{Accepted Manuscript}

Organic matter characterisation and turnover in the sediment and seawater of a tourist harbour

Cristina Misic, Anabella Covazzi Harriague

PII:

S0141-1136(09)00082-8

DOI:

10.1016/j.marenvres.2009.06.012

Reference:

MERE 3351

To appear in:

Marine Environmental Research

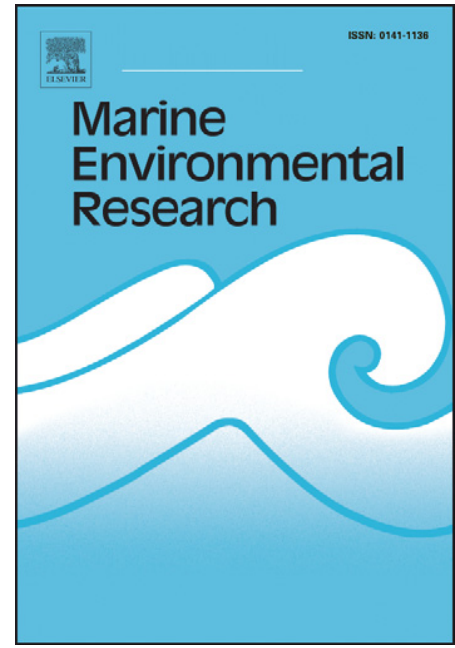

Received Date: $\quad 20$ January 2009

Revised Date: $\quad 10$ June 2009

Accepted Date: $\quad 15$ June 2009

Please cite this article as: Misic, C., Harriague, A.C., Organic matter characterisation and turnover in the sediment and seawater of a tourist harbour, Marine Environmental Research (2009), doi: 10.1016/j.marenvres.2009.06.012

This is a PDF file of an unedited manuscript that has been accepted for publication. As a service to our customers we are providing this early version of the manuscript. The manuscript will undergo copyediting, typesetting, and review of the resulting proof before it is published in its final form. Please note that during the production process errors may be discovered which could affect the content, and all legal disclaimers that apply to the journal pertain. 
1

2

3

4

5

6

7

8

9

10

11

12

13

14

15

16

17

18

19

20

$21 \quad 16132$ Genova

22 Italy

23

Phone: 00390103538068

24 Fax: 00390103538140

25 e-mail: misic@dipteris.unige.it

Date of submission: 20 January 2009

\section{Corresponding author:}

Dr. Cristina Misic

\section{Università di Genova}

C.so Europa 26

of a tourist harbour

\author{
Cristina Misic and Anabella Covazzi Harriague
}

Dipartimento per lo Studio del Territorio e delle sue Risorse, Università di Genova

C.so Europa 26, 16132 Genova, Italy

\title{
Organic matter characterisation and turnover in the sediment and seawater
}

Submitted for publication to: Marine Environmental Research

Date of submission of the revised version: 7 May 2009

Date of submission of the second revision: 10 June 2009

Dipartimento per lo Studio del Territorio e delle sue Risorse 


\section{Abstract}

2 A survey of a Ligurian tourist harbour was carried out during winter 2006 and summer 2007 in

3 order to study the organic matter (OM) turnover through extracellular enzymatic activity. Seawater

4 and sediments were sampled at six stations, three inside the port boundaries, one outside the port

5 and two in an area influenced by the outflow of a minor river (Boate). The seawater showed OM

6 turnover times similar to other oligo-mesotrophic coastal areas, and low concentrations of

7 chlorophyll-a and inorganic nutrients. The sediments, instead, revealed high OM loads and a

8 predominance of proteolysis. A significant reduction of the OM loads was observed in the outside

9 station, indicating that the OM accumulation was due to the structures and activities of the harbour

10 and to the Boate influence. The OM biotic recycling via enzymatic activity was enhanced especially

11 during summer. Although the carbohydrates were probably highly refractory, their turnover was

12 notably faster, due to glycolytic enzymatic activity that was enhanced more than the proteolytic in

13 both the sediment and in the seawater. This suggested that the removal and recycling of OM were

14 potentially efficient, and prevented the shift to eutrophication of the Rapallo harbour area.

15

16 Key words: organic matter, hydrolytic enzymatic activity, turnover times, harbour, NW 17 Mediterranean. 


\section{1. Introduction}

2 The efficiency of organic matter (OM) recycling is crucial at harbour sites because the sediment and

3 seawater are nearly always characterised by extremely high organic matter contents, depending on

4 several factors such as eutrophication, sedimentary texture, allochthonous inputs, low

5 hydrodynamism (Estacio et al., 1997; Danulat et al., 2002; Guerra-García and García-Gómez,

6 2005). Biotic consumption and degradation, that should be the main processes of OM mobilisation,

7 are not often efficient enough to maintain the ecosystem balance, due to the excess of detrital OM,

8 increasing anoxic conditions and, often, the presence of significant levels of contamination by

9 heavy metals and other toxic components (Cornelissen et al., 2008; Kaufman et al., 2004). In

10 addition, the occurrence of biochemical interactions between labile $\mathrm{OM}$ and recalcitrant $\mathrm{OM}$

11 molecules (humic acids for instance, Hubberten et al., 1994) originating from allochthonous

12 continental inputs (rivers, sewage) may modify the turnover times and pathways of organic matter

13 recycling.

14 In some cases mechanical removal via dredging seems to be the only way to bypass the problems

15 arising from OM loads, although chemical and biological techniques have been proposed to

16 mitigate the deleterious effects of OM excess (Murphy et al., 1999). In order to improve the natural

17 self-repair and/or to choose a suitable, eco-sustainable intervention, knowledge of the peculiar

18 pathways of OM recycling in a harbour environment is fundamental to gathering significant and

19 low-cost results (Fabiano et al., 2003).

20 The biological recycling of OM starts with the consumption and degradation of detrital OM by

21 microbes, carried out especially (but not exclusively) by bacteria. Due to their small size, bacteria

22 have firstly to cut the polymeric compounds into smaller units by means of extracellular enzymatic

23 activities, whose features have been considered as proxies of OM turnover and bioavailability and,

24 in turn, of potential diagenetic fate (Manini et al., 2003; Caruso et al., 2005; Danovaro et al., 2005).

25 The present study aims to investigate the main pathways of OM degradation in Rapallo Harbour, 26 one of the main tourist harbours of Liguria (NW Mediterranean). OM turnover through extracellular 
1 enzymatic activities is determined to highlight the potential responses of the ecosystem to sediment

2 mobilisation and OM loads, with special emphasis on the quality of the OM (available for or

3 refractory to consumption).

4

\section{Material and Methods}

\subsection{Study site}

7 Rapallo Harbour is the largest tourist harbour in the Marconi Gulf, and is divided into two basins:

8 the public port and the private Carlo Riva International Tourist Port (Fig. 1). The dominant coastal

9 current enters from the east, generating feeble internal circulation from the public (maximum $4 \mathrm{~m}$ deep) to the private sector ( $9 \mathrm{~m}$ deep), which was built to facilitate the movement and mooring of

11 large recreational vessels. The small river Boate (generally carrying coarse organic and inorganic debris, and used seasonally for mooring small recreational boats) empties into the northern part of

13 the harbour, which is protected from a massive flow of freshwater from the Boate by a concrete 14 pier. The harbour and the Boate receive surface runoff and uncontrolled wastewaters, both 15 municipal and from small factories and farms situated along the $1.9 \mathrm{~km}$ course of the small river.

\subsection{Sampling}

Sampling was carried out during December 2006 and July 2007 at 6 stations (Fig. 1). Stations 1 and 2 were placed in the private sector of the harbour, station 4 was placed in the public sector, stations 5 and 6 at the mouth of the Boate. Station 3, was situated immediately outside the harbour. At each station temperature $\left({ }^{\circ} \mathrm{C}\right)$ and salinity profiles were acquired using a Sea Bird probe (SBE 19).

22 Turbidity was measured with a Hach 2100P turbidimeter, calibrated for turbidity using the formazine mixtures, and expressed as formazine turbidity units (ftu).

24 Seawater was collected from the water layer next to the sediment ( $1 \mathrm{~m}$ above the bottom) using a

25 Niskin bottle. Sediment samples were collected using a modified Van Veen grab (surface area 216

$\left.26 \mathrm{~cm}^{2}\right)$. The surface layer $(0-2 \mathrm{~cm}$ depth) was collected. 
2

3 For the dissolved oxygen determination, subsamples of seawater were carefully collected from the

\subsection{Sample treatment} bottle, avoiding air bubbles, fixed and analysed following Carpenter (1965). Seawater and sediment subsamples were immediately processed for the enzymatic analyses as described below. Subsamples for bacterial counts (both seawater and sediment) were stored with buffered formalin (2 $\%$ final concentration). Acetone was immediately added to the sediment subsamples for the phytopigment extraction. The remaining sediment was stored at $-20^{\circ} \mathrm{C}$ until analysed for the $\mathrm{OM}$ content.

Seawater was transferred to the laboratory within two hours of sampling. Seawater subsamples were filtered through $0.45 \mu \mathrm{m}$ pore-size membranes and the filtered seawater was analysed for dissolved chromophoric organic compounds and inorganic nutrients. Seawater subsamples (500-1000 ml) were filtered through Whatman GF/F filters in order to retain the particulate suspended fraction. The filters for the phytopigment extraction were immediately placed in acetone. The other filters were stored at $-20^{\circ} \mathrm{C}$ for the organic matter analyses.

\subsection{Analytical procedures}

Inorganic nutrient (nitrite+nitrate and ortophosphate) concentrations were determined following Hansen and Grasshoff (1983) with a Nutrient Probe Analyser SYSTEA.

Dissolved chromophoric compounds were determined using synchronous fluorescence spectroscopy, an instrumental technique that involves the simultaneous scanning of excitation and emission monochromators, keeping a constant difference between them. Generally, the lower the difference, the higher the resolution. We utilised a difference of $25 \mathrm{~nm}$, as suggested by Ferrari and Mingazzini (1995). The 2D-spectra, obtained with a Jasco FP50 spectrofluorometer, were corrected by comparison with the spectrum of ultrapure water (Coble, 1996). We focused on two categories of dissolved organic matter, defined by an excitation wavelength between 275 and $300 \mathrm{~nm}$ (protein- 
1 like signal) and between 325 and $400 \mathrm{~nm}$ (humic-like signal) (De Sousa Sierra et al., 1994). Due to

2 the semi-quantitative nature of the analysis, the results were expressed as fluorescence units (fu).

3 Seawater and sedimentary chlorophyll-a were extracted according to Holm-Hansen et al. (1965).

4 The Jasco FP50 spectrofluorometer was calibrated with a solution of chlorophyll-a from Anacystis

5 nidulans. Autotrophic biomass was calculated by converting the chlorophyll-a concentration to

6 carbon content, using a conversion factor of 40 (de Jonge, 1980).

7 For the determination of $\mathrm{OM}$, the seawater and sedimentary proteins and the carbohydrates were

8 estimated according to Hartree (1972) and Dubois et al. (1956), respectively. A Jasco V-500

9 spectrophotometer was calibrated with bovine serum albumin and glucose solutions. Proteins and

10 carbohydrates were converted into carbon equivalents using a factor of 0.49 and 0.40 for proteins

11 and carbohydrates, respectively (Fabiano et al., 1995).

Bacteria counts were performed with epi-fluorescence microscopy (Zeiss Universal Microscope) using $0.2 \mu \mathrm{m}$ black Nuclepore filters after acridine orange staining (Hobbie et al. 1977). The

14 contribution of different size classes to the total bacterial biomass was evaluated by assigning 15 bacteria to different size classes, small-size bacteria (diameter $<0.5 \mu \mathrm{m}$, volume $=0.065 \mu \mathrm{m}^{3}$ ) 16 medium-size bacteria (diameter from 0.5 to $1 \mu \mathrm{m}$, volume $=0.320 \mu \mathrm{m}^{3}$ ), large-size bacteria 17 (diameter from 1 to $2 \mu \mathrm{m}$, volume $=0.574 \mu \mathrm{m}^{3}$ ), and by converting the biovolume into carbon

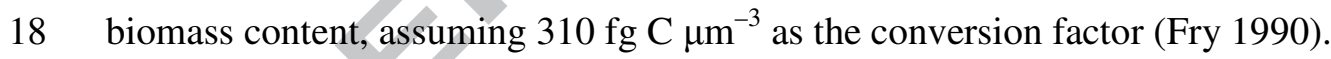

19 The ectoenzymatic kinetic parameters ( $\operatorname{mmax}$ and $\mathrm{Km}$ ) of $\beta$ glucosidase (BG) and leucine 20 aminopeptidase (LA) were determined using gradual concentrations $(62.5,125,250,500$ and 1000 $21 \mu \mathrm{M}$ final concentration) of 4-methylumbelliferyl glucoside (excitation at $365 \mathrm{~nm}$ and emission at $22460 \mathrm{~nm}$ ) and of L-leucine 7-amido-4-methylcoumarin hydrochloride (excitation at $380 \mathrm{~nm}$ and emission at $440 \mathrm{~nm}$ ) respectively (Hoppe, 1983). The samples and controls (sample water and sediment boiled as a blank for the accidental contamination due to handling and for abiotic cleavage of the artificial substrates) were incubated in duplicate with $0.5 \mathrm{ml}$ of substrate solution for $5 \mathrm{~h}$. 
1 FP50 spectrofluorometer previously calibrated with 4-methylumbelliferone and 7-amino-4-

2 methylcoumarin solutions. The kinetic parameters were determined from a Michaelis-Menten

3 model.

4 LA and BG activities were converted into equivalents of $\mathrm{C}$ mobilised assuming that $1 \mathrm{nmol}$ of

5 substrate hydrolysed enzymatically corresponded to $72 \mathrm{ng}$ of mobilised C (Caruso et al., 2005).

6 The OM turnover times (days) were calculated converting proteins and carbohydrates into C

7 equivalents and then dividing by the the LA and BG activities transformed in equivalent of C 8 mobilised.

9

\subsection{Statistical analyses}

We tested the differences between the results of a single variable over the different sampling dates with one way ANOVA analysis. To test the relationships between the various variables, a Spearman-rank correlation analysis was performed. We used the PRIMER $6 \beta$ programme package to perform cluster analyses of the 4th-root-transformed data to reveal similarities between sampling dates. The considered variables were: enzymatic activities $\left(\mathrm{V}_{\max }\right.$ and $\left.\mathrm{K}_{\mathrm{m}}\right)$, organic matter, bacterial and autotrophic biomass. Similarities were calculated using Euclidean distances. The complete group linkage method was used to calculate dendrograms. Similarity percentage analysis (SIMPER) was used to analyse variable dominance. LINKTREE analysis was applied to the seawater matrix to test which environmental variable (salinity, turbidity, dissolved oxygen, inorganic nutrient concentrations, dissolved $\mathrm{OM}$ ) determined the main differences between stations.

\section{Results}

\subsection{Environmental variables and dissolved organic matter}

Table 1 reports the results related to the environmental variables. Significant increases $(\mathrm{p}<0.01)$ were observed from December to July for temperature (from $16.4 \pm 0.3$ to $23.9 \pm 1.2{ }^{\circ} \mathrm{C}$ ), salinity (from $36.3 \pm 1.0$ to $38.4 \pm 0.3$ ) and turbidity (from $2.73 \pm 1.23$ to $5.08 \pm 1.16 \mathrm{ftu}$ ). In particular, the 
1 increase of turbidity was highly significant for the harbour-influenced stations (1, 2 and 4)

2 ( $\mathrm{p}<0.001)$. Dissolved oxygen (DO) and the nutrient concentrations, instead, decreased significantly

3 (from $8.8 \pm 0.9$ to $7.7 \pm 0.4 \mathrm{mg} \mathrm{l}^{-1}$ for $\mathrm{DO}, \mathrm{p}<0.05$; from $2.4 \pm 0.6$ to $0.8 \pm 0.3 \mu \mathrm{M}$ for nitrite + nitrate and

4 from $0.24 \pm 0.02$ to $0.15 \pm 0.03 \mu \mathrm{M}$ for phosphate, $\mathrm{p}<0.001$ ).

5 Comparing the outside station 3 with the others, we observed significantly lower turbidity yalues

$6 \quad(\mathrm{p}<0.001$ for December, $\mathrm{p}<0.05$ for July). Considering the nutrient concentrations, only

7 nitrite+nitrate at the July sampling were lower at station 3 compared to the others $(\mathrm{p}<0.05)$. No

8 differences were observed for the DO.

9 December showed turbidity values significantly lower $(\mathrm{p}<0.05)$ at the harbour stations $(2.37 \pm 0.91$

$10 \mathrm{ftu})$ compared to the Boate-influenced ones $(3.71 \pm 1.15 \mathrm{ftu})$, where significantly higher DO values

$11(\mathrm{p}<0.001)$ were observed, probably due to the shallower depth. The stations influenced by the Boate

12 (especially station 6) showed significantly higher phosphate concentrations during July $(\mathrm{p}<0.05)$

13 compared to the harbour ones.

14 Table 1 reports the results related to the fluorescent dissolved organic matter. While no differences

15 were observed comparing the December and the July samplings for the Boate stations (22.0 \pm 2.9 and

$1621.5 \pm 3.1 \mathrm{fu}$ for protein-like and $26.6 \pm 13.8$ and $16.4 \pm 7.5$ fu for humic-like), the harbour ones

17 showed significant increases of both protein-like (from 12.1 \pm 2.9 to $59.7 \pm 16.9 \mathrm{fu}$ ) and humic-like

18 signals (from $7.6 \pm 5.4$ to $38.7 \pm 34.5 \mathrm{fu})(\mathrm{p}<0.001)$. The outside station 3 showed values

19 significantly lower than the other stations for the July sampling $(\mathrm{p}<0.001)$.

\subsection{Autotrophic and bacterial biomasses}

22 Comparing the autotrophic biomass of the seawater of December and July, we observed similar

23 values for the harbour stations $\left(19.3 \pm 2.3\right.$ and $\left.11.8 \pm 11.7 \mu \mathrm{g}^{-1}\right)$, but a significant increase for the

24 Boate stations (from 16.2 \pm 1.6 and 102.8 $\left.\pm 12.9 \mu \mathrm{g} \mathrm{l}^{-1}\right)(\mathrm{p}<0.001)$. The autotrophic biomass (Fig. 2A)

25 of the outside station 3 showed values significantly higher $(\mathrm{p}<0.001)$ in the seawater of December

26 compared to the other stations, while they were significantly lower $(\mathrm{p}<0.05)$ for July. The 
1 autotrophic biomass of the sediment (Fig. 2C) showed a significant $(\mathrm{p}<0.001)$ decrease from

2 December $\left(113.5 \pm 67.9 \mathrm{ng} \mathrm{C} \mathrm{g}^{-1}\right)$ to July $\left(9.2 \pm 5.5 \mathrm{ng} \mathrm{C} \mathrm{g}^{-1}\right)$. While in December, the outside station

33 showed a significantly lower content of sedimentary autotrophic biomass $(\mathrm{p}<0.05)$, a more

4 homogeneous distribution was recorded for July.

5 Considering the bacterial biomass, the comparison of the seawater data of December and July (Fig.

6 2B) highlighted a slight increase in July (from $8.8 \pm 1.7$ to $9.7 \pm 2.8 \mu \mathrm{gC}^{-1}$ ). Instead a significant

$7 \quad(\mathrm{p}<0.05)$ decrease for the sedimentary bacterial biomass (from $25.7 \pm 8.9$ to $16.9 \pm 9.1 \mu \mathrm{gC} 1^{-1}$ ) (Fig.

8 2D) was observed. In July the bacterial biomass of the sediment of station 3 was significantly lower

$9 \quad(\mathrm{p}<0.01)$ than in the other stations.

10 Both the seawater and the sediment showed a significant increase $(\mathrm{p}<0.05)$ from December to July

11 of the bacterial: autotrophic biomass ratio values (for the seawater: $0.5 \pm 0.1$ vs. $1.4 \pm 1.2$; for the 12 sediment: $0.3 \pm 0.1$ vs. $2.4 \pm 1.7)$.

\subsection{Enzymatic activity}

15 Significant increases of enzymatic activity from December to July were observed in the seawater 16 (Fig. 3A and B) (LA: from $119.3 \pm 25.9$ to $703.0 \pm 282.8 \mathrm{nmol} \mathrm{l}^{-1} \mathrm{~h}^{-1}$; BG: from $0.6 \pm 0.2$ to $10.1 \pm 4.4 \mathrm{n}$ $17 \mathrm{~mol} \mathrm{l}^{-1} \mathrm{~h}^{-1}, \mathrm{p}<0.001$ ), and in the sediment (Fig. 3C and D) (LA: from 38.0 \pm 11.8 to $125.3 \pm 77.6 \mathrm{n}$ mol $18 \mathrm{~g}^{-1} \mathrm{~h}^{-1}$; BG: from $1.9 \pm 1.7$ to $\left.7.3 \pm 3.1 \mathrm{n} \mathrm{mol} \mathrm{g}^{-1} \mathrm{~h}^{-1}, \mathrm{p}<0.01\right)$. The BG activity generally had higher 19 increases (7-fold in the sediment and 18-fold in the seawater) compared with LA (4 and 6 times in 20 the sediment and seawater, respectively) from December to July.

21 Comparing the different zones of the sampling area, in the seawater the ouside station 3 showed 22 generally significantly lower enzymatic activity $(\mathrm{p}<0.05)$ compared to the other stations. In the 23 sediment the BG activity was significantly lower at station $3(\mathrm{p}<0.05)$, while no differences were 24 observed for LA activity. 
1 The enzymatic activity was significantly related to the turbidity. The correlations were significant

2 for the seawater ( $r=0.68$ for LA and $r=0.66$ for $B G, p<0.05, n=12$ ), and for the sediment (LA:

$3 \mathrm{r}=0.72, \mathrm{n}=10, \mathrm{p}<0.05, \mathrm{BG}: \mathrm{r}=0.88, \mathrm{n}=11, \mathrm{p}<0.001)$.

4 The LA:BG ratio values showed the predominance of proteolysis (on average $138.1 \pm 86.3$ in the

5 seawater and $29.3 \pm 27.2$ in the sediment).

6 Enzyme affinity for substrates (Table 2) generally showed no differences between December and

7 July. The only significant difference was recorded for the seawater $\mathrm{LA}_{\mathrm{Km}}$, which showed higher

8 values during July $(\mathrm{p}<0.01)$.

9

\subsection{Organic matter}

The seawater particulate protein and carbohydrate concentrations (Fig. 4A and B) were significantly higher $\left(\mathrm{p}<0.01\right.$ ) in July (protein: from $126.2 \pm 27.4$ to $319.4 \pm 59.9 \mu \mathrm{g} \mathrm{l}^{-1}$; carbohydrate: from $68.4 \pm 16.0$ to $145.0 \pm 37.3 \mu \mathrm{g}^{-1}$ ). The particulate protein concentrations were lower at the outside station 3, while the particulate carbohydrates showed no differences. In the sediment (Fig. 4C and D) we observed a significant decrease $(\mathrm{p}<0.05)$ for the carbohydrate content at July (from 5711.2 \pm 4294.9 to $2858.5 \pm 1570.3 \mu \mathrm{g} \mathrm{g}^{-1}$ ). The decrease of carbohydrates was observed at stations 2 , 4 and 5 , while proteins decreased significantly $(\mathrm{p}<0.05)$ at station 5 . Station 3 , placed outside the harbour, had significantly lower carbohydrate and protein content $(\mathrm{p}<0.001)$ in the sediment for both samplings. Significant correlations were observed in the seawater between LA and particulate proteins $(\mathrm{r}=0.89, \mathrm{n}=12, \mathrm{p}<0.001)$ and $\mathrm{BG}$ and particulate carbohydrates $(\mathrm{r}=0.79, \mathrm{n}=12, \mathrm{p}<0.01)$. In the sediment a significant correlation between $B G$ activity and carbohydrates $(r=0.89, n=6, p<0.05)$ was observed for December.

The turnover times of particulate proteins and carbohydrates in the seawater (Fig. 5A and B) were significantly lower during July $(\mathrm{p}<0.01)$. The turnover times of proteins in the sediment $($ Fig. $5 \mathrm{C})$ were similar for the different sampling dates $(\mathrm{p}>0.05)$, also due to the high variability observed at the stations. The turnover times of sedimentary carbohydrate (Fig. 5D) were, instead, significantly 
1 lower during July $(\mathrm{p}<0.001)$. The protein turnover rate was 48 times faster than the carbohydrate

2 rate in the sediments and 71 times faster in the seawater.

3

$4 \quad 3.5$ Cluster analysis

5 The multivariate analysis performed on the seawater data (Fig. 6A) confirmed the strong 6 differentiation between December and July samplings. The enzymatic activity and the particulate 7 protein concentrations explained up to $70 \%$ of this grouping (SIMPER analysis). The LINKTREE 8 analysis indicates that the changes of salinity (significantly higher at July) and of the inorganic 9 nutrient supply (significantly lower) exerted a strong influence on the OM production and on its degradation via enzymatic activity. The December group was further divided into two parts, mainly due to LA activity, particulate protein and carbohydrate concentrations (explaining $71 \%$ of the differentiation, SIMPER analysis). Salinity, turbidity and nitrite+nitrate concentration were related to this grouping (LINKTREE analysis). The July sampling showed a division driven by chlorophyll-a (autotrophic biomass) and by enzymatic activities (78\%, SIMPER analysis). The significantly higher phosphate concentrations observed in the Boate stations, linked to this grouping (LINKTREE analysis), should have enhanced the primary biomass development and the related autotrophic and bacterial enzyme activity.

The Fig. 6B reports the results of the multivariate analysis performed on sediment data. The grouping of December and July sampling was visible, although not so clear as for the seawater. In particular, the dendrogram indicated that in December the outside station 3 showed the lowest OM content (carbohydrate and proteins explained $72 \%$ of the difference, SIMPER analysis), but a higher autotrophic biomass (explaining 10\% of the difference, SIMPER analysis). The Boate stations in December were different compared to the harbour ones, mainly due to the higher OM and autotrophic biomass content (explaining $79 \%$ of the difference, SIMPER analysis). The harbour stations in December were more similar to the July sampling, although showing higher carbohydrate and autotrophic biomass contents, that explained $47 \%$ of the difference (SIMPER 
1 analysis). The higher LA activity in July explained 16\% of the difference (SIMPER analysis). The

2 July stations showed a homogenisation of the characteristics in the whole sampled area.

3

\section{4. Discussion}

5

Previous studies of Rapallo Harbour defined this site as an OM-rich area, although only moderately impacted by contaminants such as heavy metals (Covazzi Harriague et al., 2007). The present study confirms that after 10 years the sediments in Rapallo Harbour were characterised by a high OM content, similar to those found in eutrophic coastal areas (Fabiano et al., 2001). The significantly lower values of the outside area (namely station 3) indicated the limited spatial influence of the enrichment processes depending on the harbour structures and activities. In particular, protein and carbohydrate sediment content were much higher than those reported for the adjacent coastal areas of the Ligurian Sea (Danovaro and Fabiano, 1995; Misic and Covazzi Harriague, 2008), but they were one order of magnitude lower than those found in the larger harbour of the neighbouring city of Genoa (Fabiano et al., 2003). In the seawater the chlorophyll-a and inorganic nutrient concentrations were lower than those recorded in the waters of the eutrophic harbour of A Coruña, Spain (Varela and Prego, 2003). The seawater chlorophyll-a concentrations and the particulate OM were quite similar or only slightly higher than those recorded in the neighbouring coastal Ligurian Sea (Danovaro and Fabiano, 1997). These observations have led us to the conclusion that seawater and sediment may follow separate trophic pathways in Rapallo Harbour: the former towards mesotrophy and oligotrophy, the latter towards eutrophy and, possibly, eutrophication. The different trends of the seawater and sediments were due to the small size of the harbour and to the good internal water circulation, as revealed by the high dissolved oxygen concentrations. Furthermore, the irregular influence of the Boate did not allow permanent gradients for the studied variables. Similarly, studies carried out in larger harbours (Moreno et al., 2008) have highlighted that environmental sedimentary variables change significantly over a hundred-metre scale and do not follow a distribution gradient from the inner to the outer harbour. 
1 The OM recycling via biotic processes was performed by enzymatic activities. The origin of these

2 enzymes was not clear. In fact we observed a low bacterial contribution (Fig. 2), significantly

3 decreasing from the December sampling to the July one in the sediment, and the uncoupling of

4 enzymatic activity and bacterial biomass in the seawater and sediment. Several studies have

5 demonstrated that enzymatic activity is not only a feature of bacteria and heterotrophic organisms,

6 but also of vegetals such as unicellular algae (Dyrhman, 2005 and references therein). In our study

7 the bacterial:autotrophic biomass ratio values in the sediment and in the seawater were significantly

8 lower at December compared to July, indicating a higher potential relevance of the autotrophic

9 compartment in remineralisation processes especially during the former sampling. The values of the

10 autotrophic biomass of the harbour and Boate-influenced stations with the outside station 3, were

11 very variable both in the seawater and in the sediment, suggested that the Rapallo harbour area

12 should follow peculiar autotrophic development trends, as observed by Varela and Prego (2003) for

13 the A Coruña Harbour (NW Spain).

14 In our study we observed significant increases in enzymatic activity in both the seawater and the

15 sediment at nearly all the stations during July (Fig. 3), and these variations were the main factors

16 responsible for the grouping of the seawater stations provided by the multivariate analysis (Fig.

17 6A). Previous studies in the Rapallo harbour reported an increase of protein and carbohydrate flux

18 to the sediment during summer, with a strong reduction during winter (Covazzi-Harriague et al.,

19 2007). An increase of organic matter should naturally stimulate a higher expression of enzymatic

20 activity (Danovaro et al., 2005), as confirmed by the significant correlations found between the

21 enzymatic activity and their relative organic substrates in the seawater during our study. In addition,

22 other research performed in the adjacent coastal Ligurian Sea reported irregular increases of the

23 enzymatic activity during summer and autumn (Misic and Covazzi-Harriague, 2008) and Cividanes

24 et al. (2002) observed at coastal sites an increase of degradation processes of OM during summer.

25 Furthermore, in our study the mixing of the surface layer of the sediment with oxygenated seawater,

26 characteristic of the summer season when movements of the touristic boats increase (Covazzi 
1 Harriague et al., 2007), could have changed the chemical medium, thus facilitating the natural

2 development of oxidising activities in the water column and in the sediment.

3 Although a low temperature could be a limiting factor on enzymatic activity in seawater and

4 sediment during winter (Patel et al., 2000), the quantitative and qualitative features of the OM

5 should influence enzyme expression. The faster turnover of proteins in both the seawater and

6 sediment (Fig. 5) showed that they were the preferred substrate for degradation. The relevance of

7 proteins depends on their value both as energy and amino acid source, avoiding energy-expensive,

8 ex-novo synthesis. Especially in the sediment, the unchanged turnover time values between

9 December and July indicated that proteins were exploited at quite a constant rate in the two

10 samplings, although in the seawater the different LA $\mathrm{K}_{\mathrm{m}}$ observed between December and July

11 suggested a change of the enzyme characteristics.

12 The features of the protein degradation processes highlighted the difference between the seawater

13 and sediment. In the seawater, the comparison of our data with that collected in other areas with

14 different trophic states, showed that the LA activity $\left(75.2 \mathrm{~g} \mathrm{C} \mathrm{m}^{-3}\right.$ year $^{-1}$ during December and 443.3

$15 \mathrm{~g} \mathrm{C} \mathrm{m}^{-3}$ year ${ }^{-1}$ during July) was similar to coastal lagoons (96.2-474.5 $\mathrm{g} \mathrm{C} \mathrm{m}^{-3}$ year $^{-1}$ ) (Caruso et al.,

16 2005) characterised by oligo-mesotrophy. In contrast in the sediment, the predominance of

17 proteolysis observed during our study would indicate a tendency to eutrophication (Meyer-Reil and

18 Köster, 2000). However, the turnover times in the sediment in our sampling sites were similar to

19 those found by Manini et al. (2003) (on average about 5 days) in coastal lagoons characterised by a

20 large and efficient channelling of OM through the microbial food web to higher trophic levels.

21 The mechanical mobilisation of sediments could have influenced the protein dynamics. The

22 increased tourist activity in the harbour during summer (Covazzi Harriague et al., 2007) allowed the

23 resuspension of the sediment and exposed the organic materials embedded in the inorganic matrix

24 during winter and spring. The significantly higher turbidity values in July compared to December

25 (Table 1) especially at the harbour stations, confirmed that such resuspension processes occurred

26 and, in addition, the increases of protein-like signals, observed again at stations 1,2 and 4, but not 
1 at the outside station 3, suggested that the higher dynamism of the proteic fraction was confined to

2 the harbour area. The significant correlations between turbidity and enzymatic activity in the

3 seawater and in the sediment supported the hypothesis of stimulation of enzymatic activity by water

4 column-sediment mixing. The mechanical mobilisation of sedimentary proteins could explain the

5 decrease of the station 5 protein content. In fact, station 5 was placed at the end of a concrete pier

6 influenced by both the Boate and harbour loads, but not protected like the inner stations and

7 probably subjected to a higher exchange of seawater with the outside area. At the same time, the

8 protein resuspended in the water had likely stimulated microbial activities and might have settled on

9 the sediment of the other stations, generating allochthonous increases of both the detrital and labile

10 protein contents.

11 Referring to the statistical multivariate analysis, we observed that the sedimentary carbohydrates of 12 the Rapallo Harbour contributed to the station grouping from 22 to $46 \%$ (Fig. 6B), showing a 13 notable relevance among the other variables and, therefore, probably having a major role in the 14 harbour trophic dynamics. They showed turnover times similar to those found for coastal lagoons, 15 where a lower efficiency in OM mobilisation was observed with consequent higher retention and 16 possible burial (Manini et al., 2003). This indicated that the carbohydrate pool of the Rapallo 17 Harbour sediments should actually have been refractory, and explained the high sedimentary 18 content we found, significantly higher than the content of station 3. Nevertheless, the significant 19 correlation between BG activity and carbohydrates in December and the significantly lower 20 turnover times of carbohydrate of July indicated that, despite their refractivity, the carbohydrates 21 might contribute to the supply of energy to microbes. No significant changes in $\mathrm{BG}_{\mathrm{Km}}$ were 22 observed between the different sampling dates, indicating that the glycosidic enzyme did not change 23 its characteristics.

\section{Conclusions}


1 The main weakness of the Rapallo Harbour environment, and of harbour areas in general, is the

2 high OM content of the sediment, especially the carbohydrate content. This feature characterised

3 the area as eutrophic, where the shift to eutrophication might be quite easy. On the contrary, the

4 seawater showed oligo-mesotrophic conditions and had good oxygenation. The sediment and water

5 compartments were able to express strong enzymatic activity during summer, as a result of the

6 seasonal, natural increase of degradation activities but, partially, also due to the sediment

7 mobilisation related to the increased recreational activities, as previously observed in the same area.

8 The general reduction of the turnover times of the OM stimulated the removal and recycling of OM

9 and prevented the shift to eutrophication.

\section{6. References}

12 Carpenter, J.H., 1965. The Chesapeake Bay Institute technique for the Winkler dissolved oxygen 13 method. Limnology and Oceanography 10, 141-143.

14 Caruso, G., Monticelli, L., Azzaro, F., Azzaro, M., Decembrini, F., La Ferla, R., Leonardi, M., 15 Zaccone, R., 2005. Dynamics of extracellular enzymatic activities in a shallow Mediterranean 16 ecosystem (Tindari ponds, Sicily). Marine and Freshwater Research 56, 173-188.

17 Cividanes, S., Incera, M., López, J., 2002. Temporal variability in the biochemical composition of 18 sedimentary organic matter in an intertidal flat of the Galician coast (NW Spain). Oceanologica 19 Acta $25,1-12$.

20 Coble, P.G., 1996. Characterization of marine and terrestrial DOM in seawater using excitation21 emission matrix spectroscopy. Marine Chemistry 51, 325-346.

22 Cornelissen, G., Pettersen, A., Nesse, E., Eek, E., Helland, A., Breedveld, G.D., 2008. The 23 contribution of urban runoff to organic contaminant levels in harbour sediments near two 24 Norwegian cities. Marine Pollution Bulletin 56, 565-573. 
1 Covazzi Harriague, A., Misic, C., Petrillo, M., Albertelli, G., 2007. Stressors affecting the

2 macrobenthic community in Rapallo Harbour (Ligurian Sea, Italy). Scientia Marina 71 (4), 7053714.

4 Danovaro, R., Fabiano, M., 1995. Seasonal and interannual variation of benthic bacteria in a

5 seagrass bed (Posidonia oceanica) of the Ligurian Sea in relation to the origin, composition and

6 other environmental factors. Aquatic Microbial Ecology 9, 17-26.

7 Danovaro, R., Fabiano, M., 1997. Seasonal changes in quality and quantity of food available for

8 benthic suspension-feeders in the Golfo Marconi (North-western Mediterranean) Estuarine Coastal 9 and Shelf Science 44, 723-736.

Danovaro, R., Armeni, M., Luna, G.M., Corinaldesi, C., Dell'Anno, A., Ferrari, C.R.,

11 Fiordelmondo, C., Gambi, C., Gismondi, M., Manini, E., Mecozzi, M., Perrone, F.M., Pusceddu,

12 A., Giani, M., 2005. Exo-enzymatic activities and dissolved organic pools in relation with mucilage

13 development in the Northern Adriatic Sea. Science of the Total Environment 353, 189-203.

14 Danulat, E., Muñiz, P., García-Alonso, J., Yannicelli B., 2002. First assessment of the highly 15 contaminated harbour of Montevideo, Uruguay. Marine Pollution Bulletin 44, 554-565.

16 De Jonge,V.E. 1980. Fluctuations in the organic carbon to chlorophyll-a ratios for estuarine benthic diatom populations. Marine Ecology Progress Series 2, 345-353.

De Sousa Sierra, M.M., Donard, O.F.X., Lamotte, M., Belin, C., Ewald, M., 1994. Fluorescence spectroscopy of coastal and marine waters. Marine Chemistry 47, 127-144.

Dubois, M., Gilles, K., Hamilton, J.K., Rebers, P.A., Smith, F., 1956. Colorimetric method for

21 determination of sugars and related substances. Analytical Chemistry 28, 350-356.

22 Dyrhman, S., 2005. Ectoenzymes in Prorocentrum minimum. Harmful Algae 4, 619-627.

23 Estacio, F.J., García-Adiego, E.M., Fa, D.A., García-Gómez, J.C., Daza, J.L., Hortasand, F., 24 Gómez-Ariza, J.L., 1997. Ecological analysis in a polluted area of Algeciras Bay (Southern Spain): 25 external « versus » internal outfalls and environmental implications. Marine Pollution Bulletin 34, $26 \quad 780-793$. 
1 Fabiano, M., Danovaro, R., Fraschetti, S., 1995. A three-year time series of elemental and

2 biochemical composition of organic matter in subtidal sandy sediments of the Ligurian Sea

3 (northwestern Mediterranean). Continental Shelf Research 15, 1453-1469.

4 Fabiano, M., Marrale, D., Misic, C., 2003. Bacteria and organic matter dynamics during a

5 bioremediation treatment of organic-rich harbour sediments. Marine Pollution Bulletin 46, 1164-

61173.

7 Fabiano, M., Misic, C., Manini, E., Danovaro, R., Povero, P., Chiatti, S., 2001. Distribution and

8 biochemical composition of suspended and sedimentary organic matter in the Northern Adriatic,.in:

9 Faranda, F.M., Guglielmo, L., Spezie, G. (Eds.), Structure and Processes in the Mediterranean

10 Ecosystems, vol. 57, Springer-Verlag, Berlin, pp. 447-454.

11 Ferrari, G.M., Mingazzini, M., 1995. Synchronous fluorescence spectra of dissolved organic matter

12 (DOM) of algal origin in marine coastal waters. Marine Ecology Progress Series 125, 305-315.

13 Fry, J.C., 1990. Direct methods and biomass estimation, in: Methods in microbiology. Academic

14 Press, New York, pp 41-85.

15 Guerra-García, J.M., García-Gómez, J.C., 2005. Oxygen levels versus chemical pollutants: do they

16 have similar influence on macrofaunal assemblages? A case study in a harbour with two opposing

17 entrances. Environmental Pollution 135, 281-291.

18 Hansen, P., Grasshoff, K., 1983. Automated chemical analysis, In : Grassoff, K., Ehrhardt, M.,

19 Kremling, K. (Eds.), Methods of seawater analysis. Verlag Chemie, Weinheim (2nd ed), pp. 347-

20379.

21 Hartree, E.F., 1972. Determination of proteins: a modification of the Lowry method that gives a 22 linear photometric response. Analytical Biochemistry 48, 422-427.

23 Holm-Hansen, O., Lorenzen, C.J., Holmes, R.W., Strickland, J.D., 1965. Fluorometric 24 determination of chlorophyll. Journal du Conseil Permanent International pour l'Exploration de la 25 Mer 30, 3-15. 
1 Hobbie, J.E., Daley, R.J., Jasper, S., 1977. Use of Nuclepore filters for counting bacteria by

2 fluorescence microscopy. Applied Environmental Microbiology 33, 1225-1228.

3 Hoppe, H.-G., 1983. Significance of exoenzymatic activities in the ecology of brackish water:

4 measurements by means of methyllumbelliferyl substrates. Marine Ecology Progress Series 11, $5 \quad 299-308$.

6 Hubberten, U., Lara, R.J., Kattner, G., 1994. Amino acid composition of seawater and dissolved

7 humic substances in the Greenland Sea. Marine Chemistry 45: 121-128.

8 Kaufman, K., Chistophersen, M., Buttler, A., Harms, H., Hohener, P., 2004. Microbial community

9 response to petroleum hydrocarbon contamination in the unsaturated zone at the experimental field 10 site Vaerlose, Denmark. FEMS Microbiology Ecology 48, 387-399.

11 Manini, E., Fiordelmondo, C., Gambi, C., Pusceddu. A., Danovaro, R., 2003. Benthic microbial 12 loop functioning in coastal lagoons: a comparative approach. Oceanologica Acta 26, 27-38.

13 Meyer-Reil, L.-A., Köster, M., 2000. Eutrophication of marine waters: effects on benthic microbial 14 communities. Marine Pollution Bulletin 41 : 255-263.

15 Misic, C., Covazzi Harriague, A., 2008. Organic matter recycling in a shallow coastal zone (NW 16 Mediterranean): The influence of local and global climatic forcing and organic matter lability on hydrolytic enzyme activity. Continental Shelf Research 28, 2725-2735.

18 Moreno, M.., Ferrero, T..J., Gallizia, I., Vezzulli, L., Albertelli, G., Fabiano, M., 2008. An 19 assessment of the spatial heterogeneity of environmental disturbance within an enclosed harbour 20 through the analysis of meiofauna and nematode assemblages. Estuarine Coastal and Shelf Science $21 \quad 77,565-576$.

22 Murphy, T.P., Lawson, A., Kumagai, M., Babin, J., 1999. Review of emerging issues in sediment treatment. Aquatic Ecosystem Health and Management 2, 419-434.

24 Patel, A.B., Fukami, K., Nishijima, T., 2000. Regulation of seasonal variability of aminopeptidase 25 activities in surface and bottom waters of Uranouchi Inlet, Japan. Aquatic Microbial Ecology 21, $26 \quad 139-149$. 
1 Varela, M., Prego, R., 2003. Hydrography and phytoplankton in an isolated and non-pristine ria

2 area: the A Coruña Harbour (NW Spain). Acta Oecologica 24, 113-124.

3

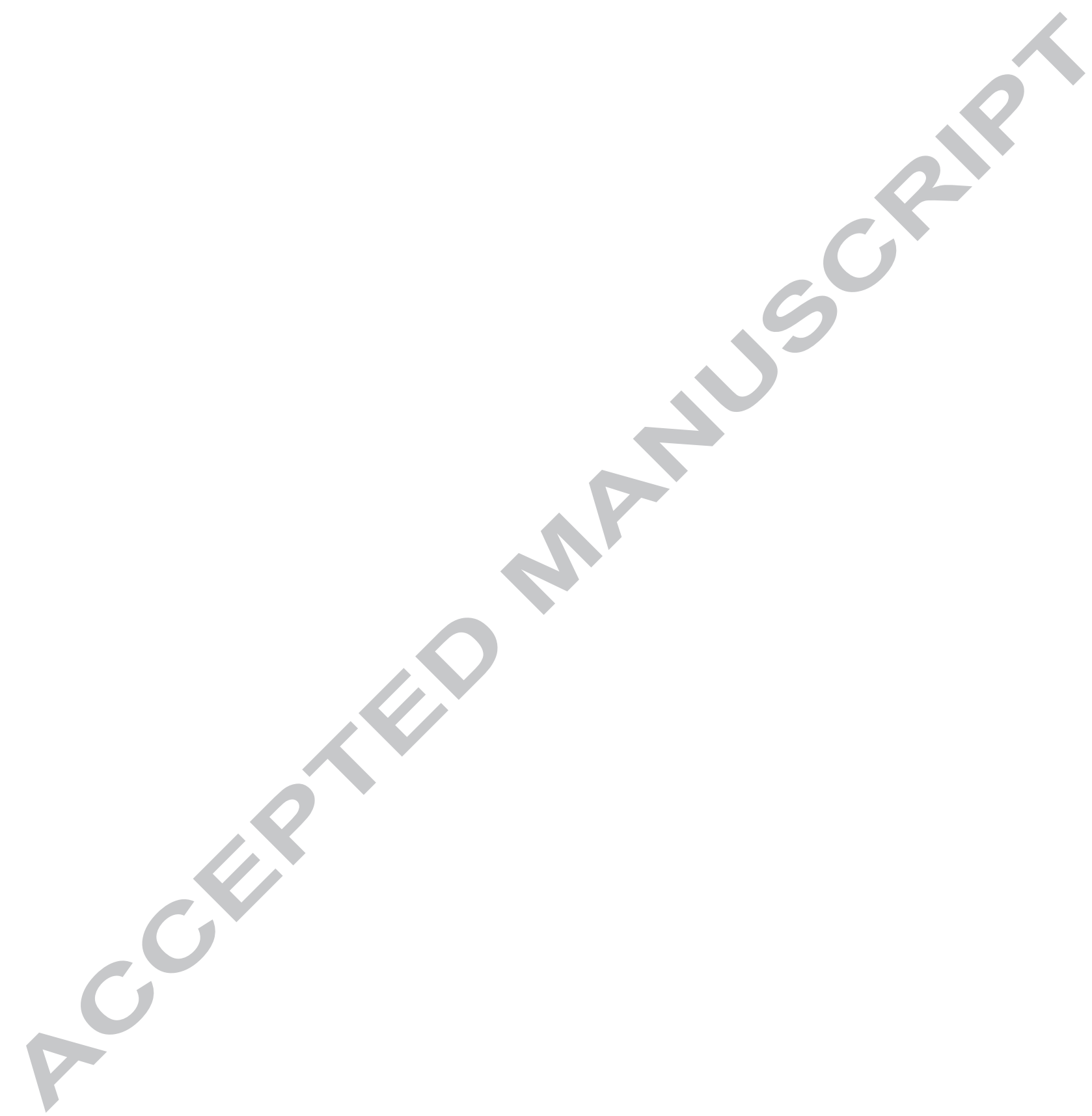


1 Table 1. Water column depth of the sampling stations and values of the physical and chemical variables of the bottom water layer (1 $\mathrm{m}$ above the 2 bottom).

\begin{tabular}{|c|c|c|c|c|c|c|c|c|c|c|c|c|c|c|c|c|c|c|}
\hline \multirow[t]{2}{*}{ Month } & \multirow[t]{2}{*}{ Station } & \multirow{2}{*}{$\begin{array}{c}\text { Depth } \\
\text { (m) }\end{array}$} & \multicolumn{2}{|c|}{ Temperature } & \multicolumn{2}{|c|}{ Salinity } & \multicolumn{2}{|c|}{ Turbidity } & \multicolumn{2}{|c|}{ Oxygen } & \multicolumn{2}{|c|}{ Nitrite+Nitrate } & \multicolumn{2}{|c|}{ Phosphate } & \multicolumn{2}{|c|}{ Protein-like } & \multicolumn{2}{|c|}{ Humic-like } \\
\hline & & & ${ }^{\circ} \mathrm{C}$ & sd & & sd & $\mathrm{ftu}$ & sd & $\mathrm{mg} \mathrm{l}^{-1}$ & sd & $\mu \mathrm{M}$ & $\mathrm{sd}$ & $\mu \mathrm{M}$ & $\mathrm{sd}$ & $\mathrm{fu}$ & sd & fu & $\mathrm{sd}$ \\
\hline \multirow[t]{6}{*}{ December } & 1 & 9 & 17.00 & 0.18 & 37.08 & 0.12 & 2.46 & 0.86 & 6.96 & 0.64 & 1.73 & 0.66 & 0.26 & 0.02 & 15.5 & 0.6 & 6.4 & 1.2 \\
\hline & 2 & 5 & 16.12 & 0.07 & 37.02 & 0.02 & 1.56 & 0.28 & 9.44 & 0.35 & 2.02 & 0.22 & 0.21 & 0.01 & 10.5 & 1.7 & 3.0 & 1.9 \\
\hline & 3 & 5 & 16.03 & 0.02 & 37.12 & 0.03 & 1.46 & 0.23 & 9.11 & 0.33 & 2.45 & 0.78 & 0.23 & 0.00 & 14.5 & 1.4 & 4.0 & 0.7 \\
\hline & 4 & 3 & 16.31 & 0.13 & 34.95 & 0.40 & 3.42 & 0.10 & 8.79 & 0.95 & 2.59 & 0.68 & 0.24 & 0.01 & 10.5 & 0.3 & 13.5 & 1.1 \\
\hline & 5 & 4 & 16.39 & 0.12 & 36.22 & 0.33 & 2.68 & 0.29 & 9.36 & 0.01 & 2.42 & 0.73 & 0.23 & 0.01 & 26.4 & 9.5 & 36.4 & 2.6 \\
\hline & 6 & 2 & 16.31 & 0.20 & 35.15 & 1.16 & 4.74 & 0.12 & 9.02 & 0.03 & 3.46 & 0.51 & 0.24 & 0.01 & 17.5 & 1.5 & 16.8 & 7.3 \\
\hline \multirow[t]{6}{*}{ July } & 1 & 9 & 22.10 & 0.18 & 38.38 & 0.06 & 5.41 & 0.32 & 7.23 & 0.09 & 0.96 & 0.02 & 0.16 & 0.02 & 46.4 & 3.5 & 18.7 & 1.5 \\
\hline & 2 & 5 & 23.64 & 0.24 & 38.20 & 0.05 & 5.63 & 0.08 & 7.88 & 0.04 & 0.58 & 0.19 & 0.15 & 0.01 & 54.1 & 8.0 & 18.8 & 2.2 \\
\hline & 3 & 5 & 23.25 & 0.06 & 38.14 & 0.07 & 3.65 & 0.46 & 8.33 & 0.42 & 0.52 & 0.02 & 0.13 & 0.01 & 14.3 & 0.3 & 13.3 & 2.0 \\
\hline & 4 & 3 & 24.34 & 0.34 & 38.69 & 0.12 & 6.26 & 0.97 & 7.59 & 0.02 & 0.66 & 0.17 & 0.10 & 0.00 & 78.8 & 6.0 & 78.5 & 5.1 \\
\hline & 5 & 4 & 25.14 & 0.15 & 38.34 & 0.04 & 5.92 & 0.32 & 7.72 & 0.06 & 0.66 & 0.22 & 0.18 & 0.01 & 19.3 & 1.8 & 11.1 & 1.9 \\
\hline & 6 & 2 & 25.01 & 0.55 & 38.93 & 0.32 & 3.61 & 0.29 & 7.65 & 0.12 & 1.29 & 0.18 & 0.17 & 0.02 & 23.8 & 7.0 & 21.7 & 15.2 \\
\hline
\end{tabular}




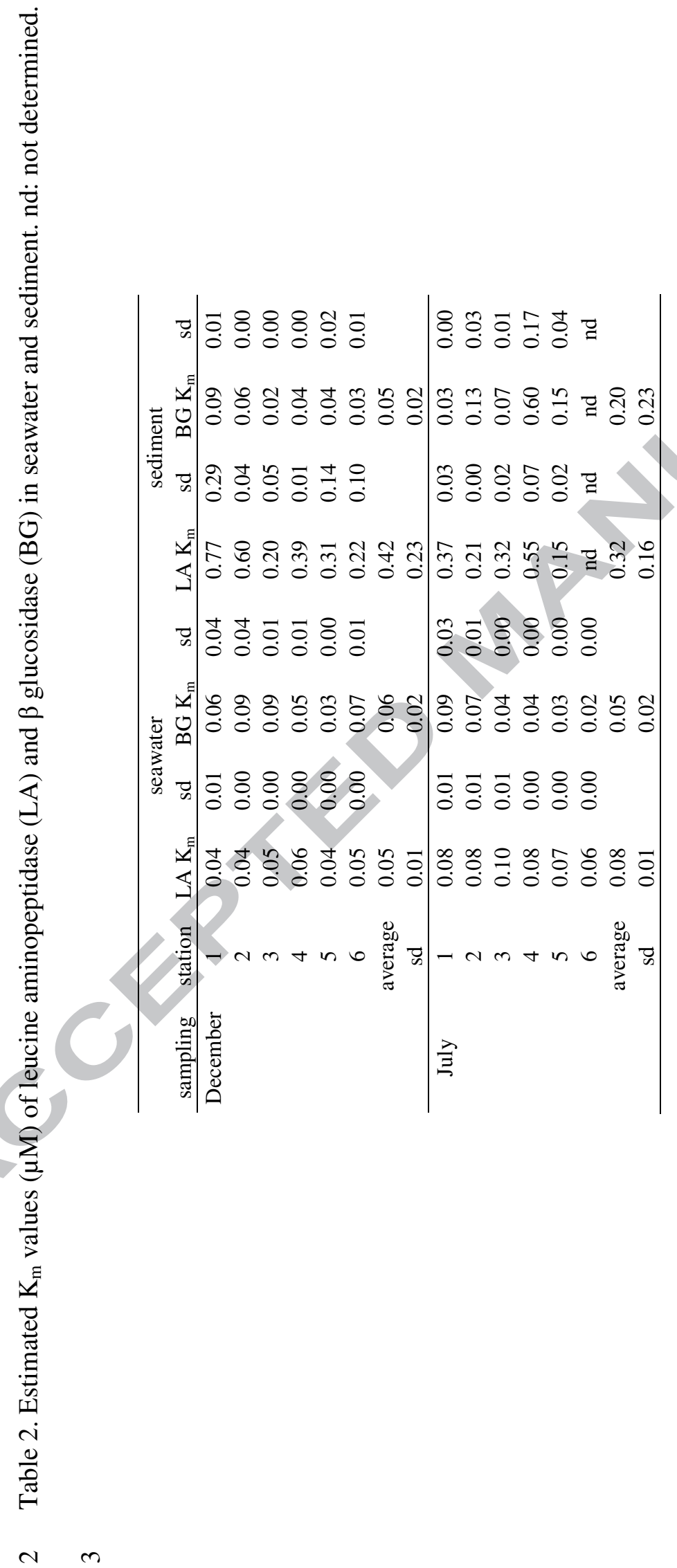




\section{Figure captions}

2 Fig. 1. Sampling sites in Rapallo Harbour (Ligurian Sea).

3 Fig. 2. Autotrophic and bacterial biomass in the water $\left(\mu \mathrm{g} \mathrm{Cl}^{-1}, \mathrm{~A}\right)$ and in the sediment $\left(\mu \mathrm{g} \mathrm{g} \mathrm{g}^{-1}\right.$,

4 B). Bars denote standard deviation. Asterisks denote significant differences $(\mathrm{p}<0.05)$ between the

5 December and July values of the same station. nd: not determined.

6 Fig. 3. Enzymatic activity $\left(\mathrm{V}_{\max }\right)$ in the seawater $\left(\mathrm{nmol} \mathrm{l}^{-1} \mathrm{~h}^{-1}\right.$, above) and sediment $\left(\mathrm{nmol} \mathrm{g}^{-1} \mathrm{~h}^{-1}\right.$,

7 below) at the six stations. LA: leucine aminopeptidase (A, C), BG: $\beta$ glucosidase (B, D). Bars

8 denote standard deviation. Asterisks denote significant differences $(\mathrm{p}<0.05)$ between the December

9 and July values of the same station. nd: not determined.

Fig 4. Organic matter. Particulate protein (A) and carbohydrate (B) concentrations in the seawater

$11\left(\mu \mathrm{g} \mathrm{l}^{-1}\right)$ and protein $(\mathrm{C})$ and carbohydrate (D) contents $\left(\mu \mathrm{g} \mathrm{g}^{-1}\right)$ in the sediment. Bars denote standard 12 deviation. Asterisks denote significant differences $(\mathrm{p}<0.05)$ between the December and July values 13 of the same station. nd: not determined.

14 Fig. 5. Potential turnover time (days) for proteins (A, C) and carbohydrates (B, D) in the seawater 15 (upper) and the sediment (lower), nd: not determined.

16 Fig. 6. Cluster analysis performed on seawater (A) and sediment (B) variables (see text for explanations). At each significant grouping, the dominant variables (SIMPER analysis) are reported with their contribution (\%). Plus and minus indicate the group showing, respectively, the highest and lowest values of the dominant variables. 

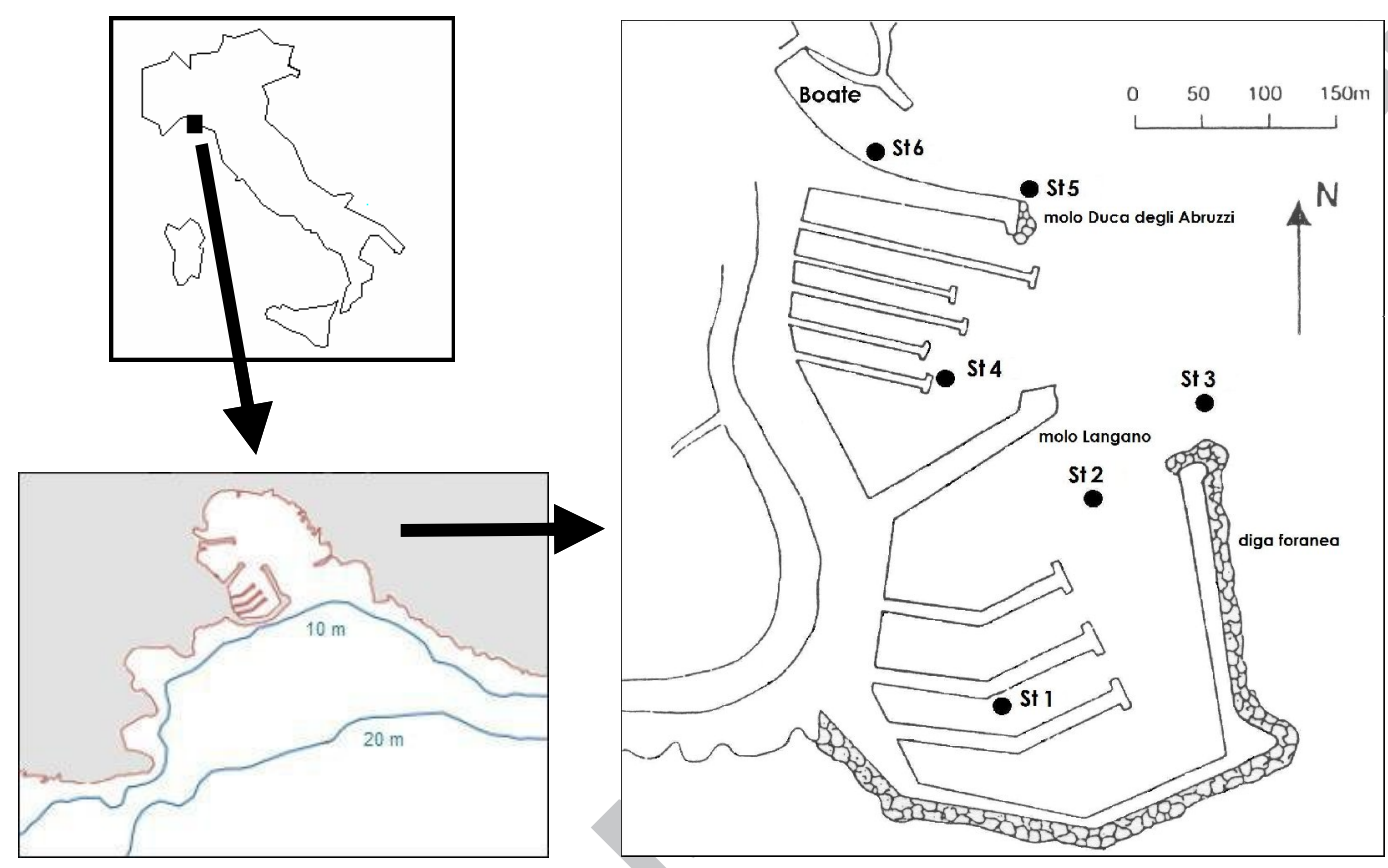

Figure 1 

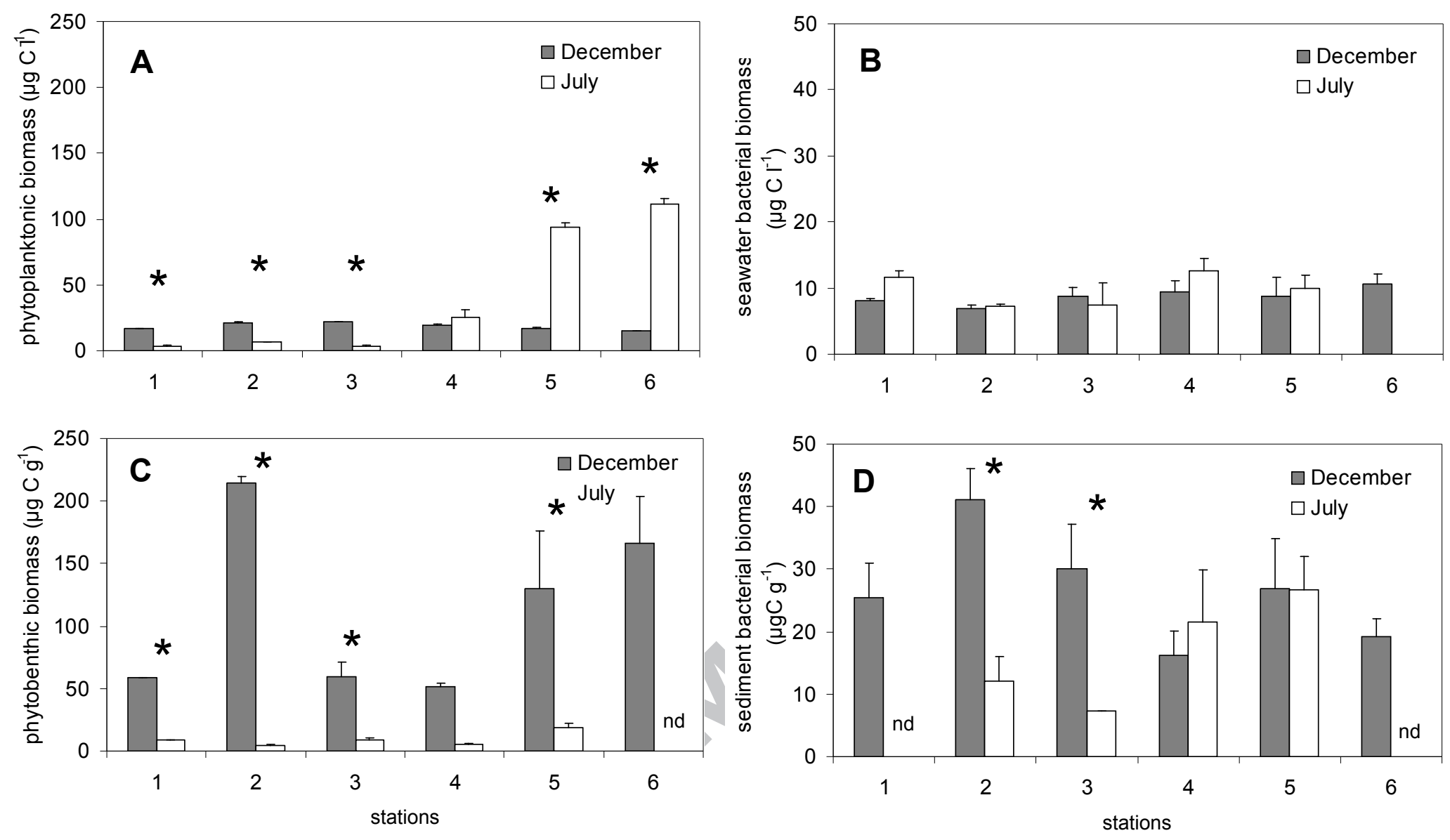

Figure 2 

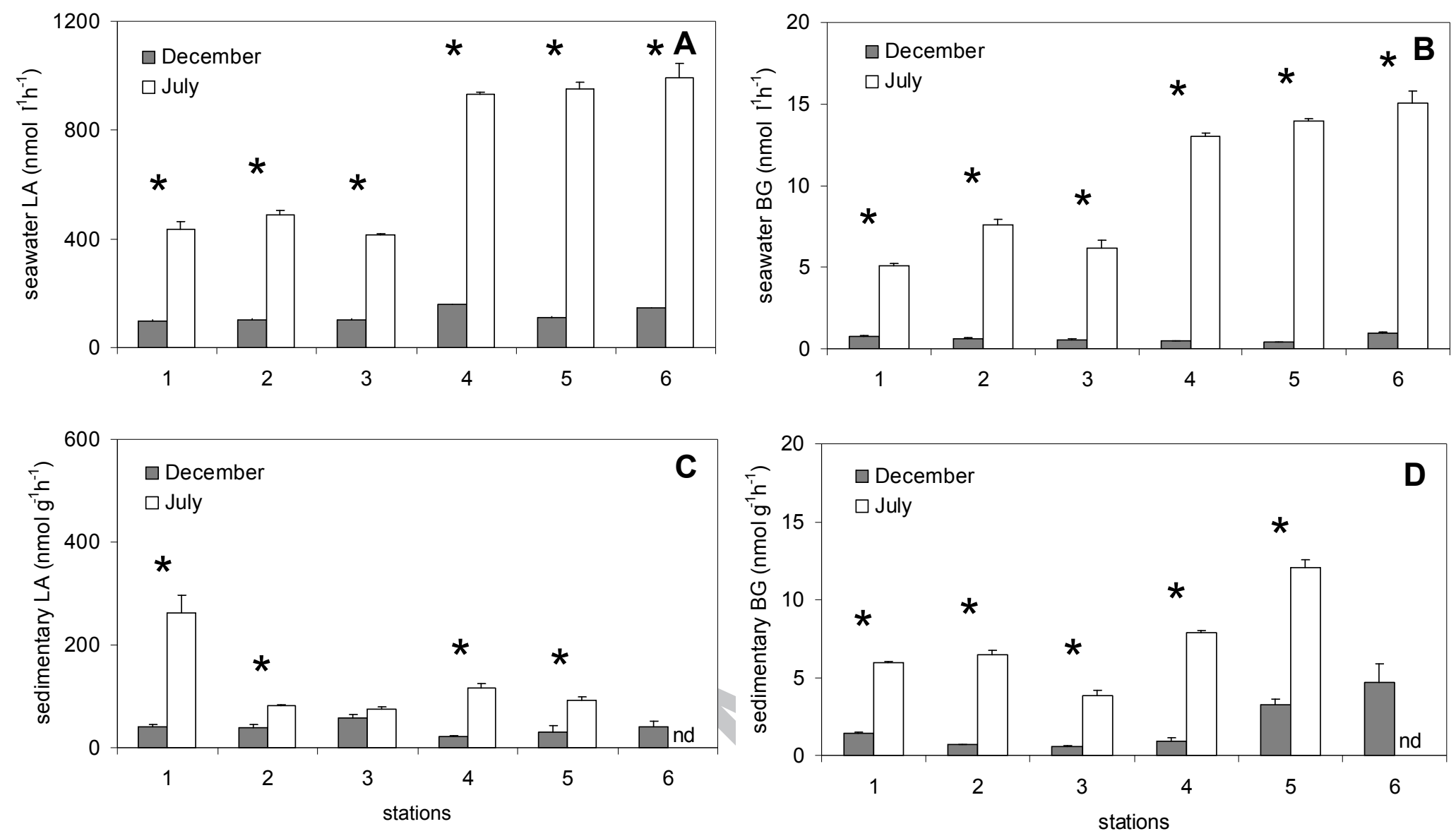

Figure 3 

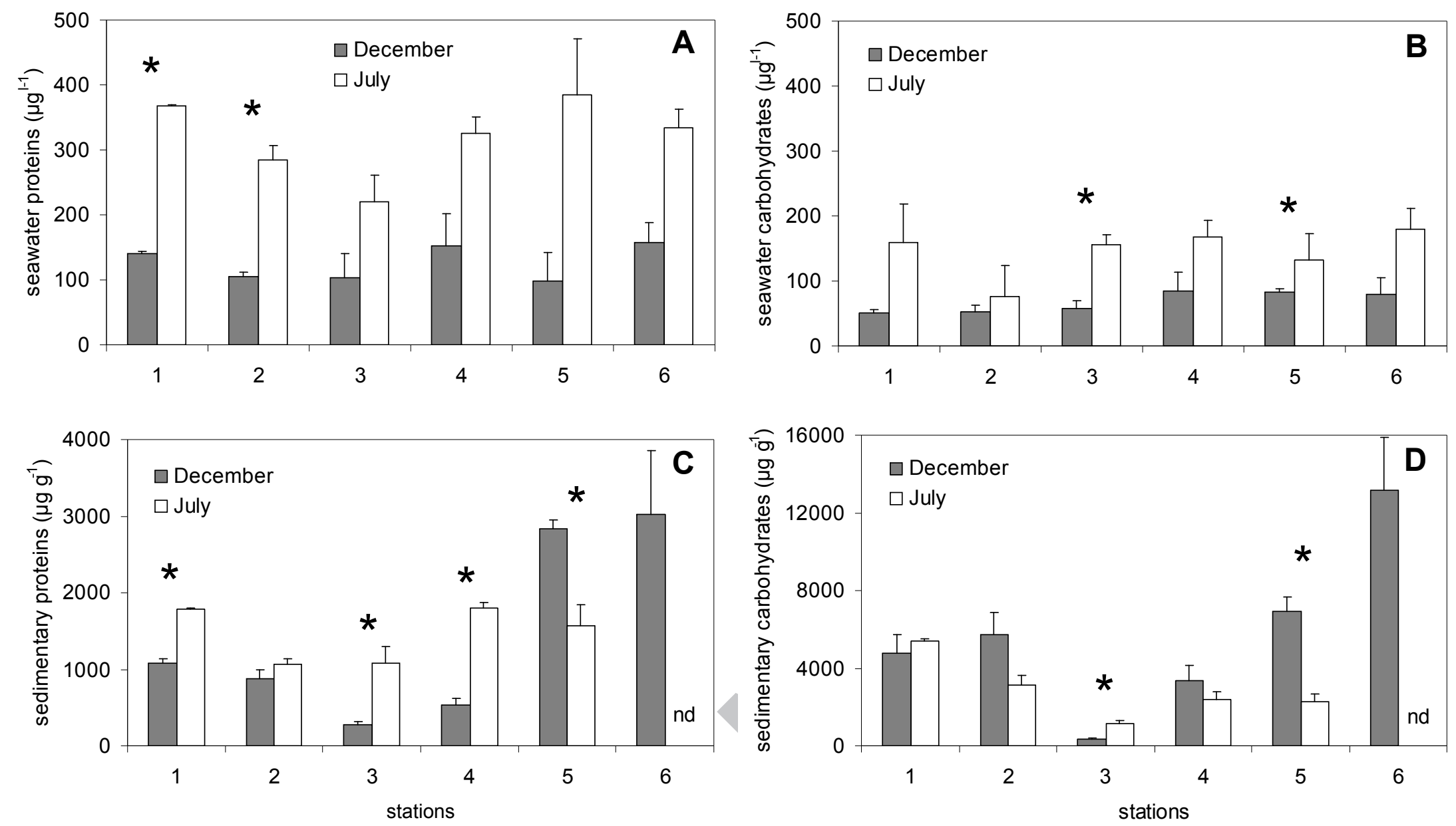

Figure 4 

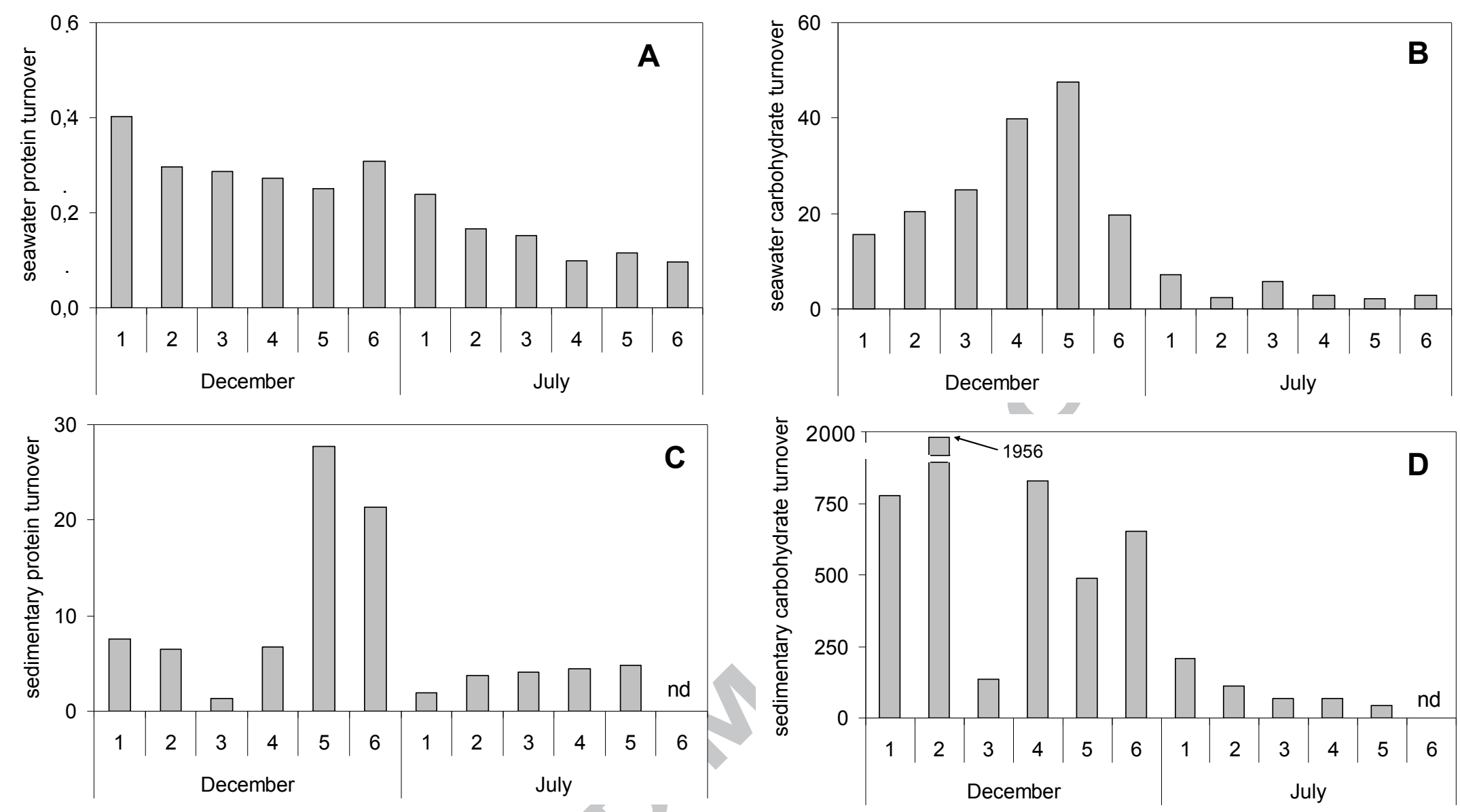

Figure 5 

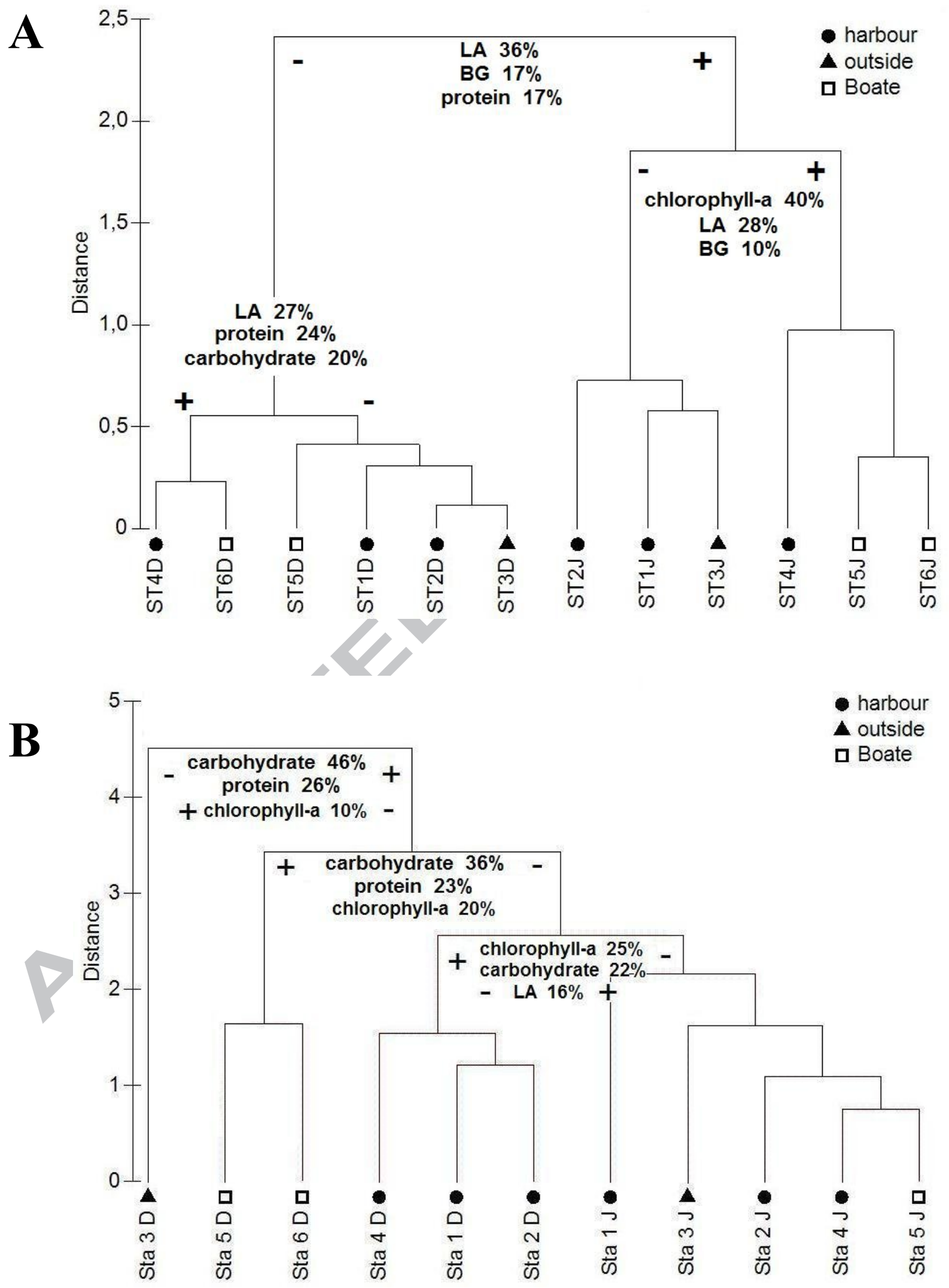

Figure 6 